\title{
Identification and Validation of a Microsatellite Marker for the Seedling Resistance Gene Lr24 in Bread Wheat
}

\author{
Pallavi JK' ${ }^{1}$, Anupam Singh ${ }^{2}$, Usha Rao I' and Prabhu KV ${ }^{2 *}$
}

${ }^{1}$ Department of Botany, University of Delhi-110007, New Delhi, India

${ }^{2}$ National Phytotron Facility, Indian Agricultural Research Institute, New Delhi-110012, India

\begin{abstract}
The background of PBW343, the high yielding and widely cultivated bread wheat cultivar of the Indian subcontinent was utilized. We were able to identify specific microsatellite markers for Agropyron elongatum derived seedling resistance gene $L r 24$. The two markers, Xgwm114 and Xbarc71 were mapped at a distance of $2.4 \mathrm{cM}$ from Lr24 locus. They can be unquestionably utilized as landmarks for identification of these genes. An $F_{2}$ population segregating for $L r 24$ and $L r 48$ in the background of PBW343 was utilized for this study. Though phenotypic reaction of the plants of the progeny populations to leaf rust infection was recorded in the seedling stage, it was difficult to perform the same in the adult plant stage as more than one gene effective against the same pathogen act mutually thus making it difficult to interpret and differentiate the resistance reaction of each of the two different genes. This is a major aspect of concern for many plant breeders in various gene pyramiding experiments since differentiating virulences of pathogens for each and every gene utilized cannot be available within all geographic locations. Molecular markers play a significant role in all such cases.
\end{abstract}

Keywords: Microsatellite markers; Lr24; Seedling resistance; Bread wheat

\section{Introduction}

Puccinia triticina, the causative ofleaf rust, is a considerable pathogen in wheat which results in substantial amount of losses by decreasing the yield in almost all wheat growing areas of the world. Deployment of rust resistance genes into the cultivar is being used to provide resistance against the locally prevalent pathogen races as an economical, enduring and eco-friendly measure [1]. Diversity for resistance to leaf rust is available in the germplasm of related wheat genera and there are many affirmative reports which assure the effectiveness of genes originating from wild relatives of the cultivated wheat in conferring long lasting rust resistance [2]. So far more than $60 \mathrm{Lr}$ genes have been identified in various wheat backgrounds [3]. Lr24 is one such resistance gene transferred into bread wheat from Agropyron elongatum which confers resistance right from the seedling stage all through the life of the plant (seedling resistance). Lr24 is being used in major wheat breeding and pyramiding programmes as a means to provide resistance to otherwise susceptible cultivars [4,5]. However, many of the seedling resistance genes when incorporated singly tend to become ineffective due the constantly evolving physiological races of the pathogen. To suppress such reviving pathogenesis, an approach to stack more than one gene into the same background has been suggested and is pursued in most of the rust resistance initiatives [6]. In this study, we have employed one such $\mathrm{F}_{2}$ population which segregates for two $L r$ genes. One of them is Lr24 and the other is a hypersensitive recessive adult plant resistance (APR) gene, $L r 48$ which confers resistance to the plant only from the time the plant reaches its booting stage and in a way decreases the selection pressure on the pathogen thus inhibiting the development of new races [2]. Differentiating the phenotypic resistance reaction of two discrete $L r$ genes existing in the same cultivar is practically impossible in the absence of individual $L r$ gene specific pathogen virulences. In such cases, the presence of exclusive DNA based markers which act as indices for each $L r$ gene will be valuable. Molecular markers are utilized on a huge scale to reduce cumbersomeness and enable rapid detection of specific $L r$ genes. Codominant molecular markers are useful in breeding programmes as only they are efficient in differentiating the heterozygous and homozygous status in plants exhibiting resistance to the pathogen infection since only the latter are significant to forward for further generations. To enable the early selection of homozygosity at the adult plant rust resistance locus, two RAPD markers $S 3_{450}$ and S336 $6_{775}$ have been utilized as a co-dominant marker system [7]. The SSR marker polymorphic for Lr24 identified in our lab will be useful in wheat breeding populations and can help in fixing the genes by the $\mathrm{F}_{2}$ population level itself without any further investment till $\mathrm{F}_{5} / \mathrm{F}_{6}$ generations.

The findings presented in this paper are a result of the work performed in N.P.F., I.A.R.I., New Delhi, India during the period 2007 to 2010 .

\section{Materials and Methods}

\section{Plant material}

An $\mathrm{F}_{2}$ population developed from the cross between the most widely cultivated and successful Indian wheat cultivar PBW343 carrying the gene Lr24 (PBW343-Lr24) developed at IARI, India and the Australian cultivar Condor derived CSP44 line (with WW80/2*WW1511/ Kalyansona parentage) carrying the gene Lr48 (CSP44-Lr48) was used for the study. Lr24 is a seedling resistance gene thus conferring resistance in all stages of the plant and $L r 48$ is an adult plant resistance gene, effective only from the time the plant reaches booting stage. The zygosity of each of the $\mathrm{F}_{2}$ individual plants was established both by $\mathrm{F}_{3}$ progeny testing and co-dominant molecular marker analysis. A set of

${ }^{*}$ Corresponding author: Pallavi JK, National Phytotron Facility, Indian Agricultural Research Institute, New Delhi-110012, India, Tel: 0091-9899023566; E-mail: jd_ research@iari.res.in

Received February 28, 2015; Accepted June 24, 2015; Published June 28, 2015

Citation: Pallavi JK, Singh A, Usha Rao I, Prabhu KV (2015) Identification and Validation of a Microsatellite Marker for the Seedling Resistance Gene Lr24 in Bread Wheat. J Plant Pathol Microb 6: 276. doi:10.4172/2157-7471.1000276

Copyright: @ 2015 Pallavi JK, et al. This is an open-access article distributed under the terms of the Creative Commons Attribution License, which permits unrestricted use, distribution, and reproduction in any medium, provided the original author and source are credited. 
30 plants per each $\mathrm{F}_{2}$ family were sown to erect the $\mathrm{F}_{3}$ population. The experiments were conducted in the controlled conditions of National Phytotron Facility, IARI, New Delhi.

\section{Pathotype of the fungal pathogen}

The inoculum of the most virulent Puccinia recondita pathotype, 77-5 (121R63-1) was obtained from the Directorate of Wheat Research, Regional Station, Flowerdale, Shimla. Inoculation of the spores of the pathotype was done by spraying inoculum suspended in water fortified with Tween- $20^{\circ}(0.75 \mu \mathrm{l} / \mathrm{ml})$ at an average concentration of 20 urediospores/microscopic field $(10 \mathrm{x} \times 10 \mathrm{x})$.

\section{DNA extraction}

Young leaves from parents and individuals of the segregating population were collected, lyophilized and ground in liquid nitrogen using a pestle and mortar. DNA extraction was performed by the microextraction method described by Prabhu et al. [8]. Final concentration of DNA samples was maintained at $10 \mu \mathrm{g} / \mu \mathrm{l}$ for PCR reactions.

\section{Seedling test}

After sampling for DNA extraction, seedlings 8-10 days old at decimal code DC 11 stage were inoculated during the evening hours [9]. Prior to inoculation, the plants were sprayed with water to provide a uniform layer of moisture on the leaf surface. After inoculation, the seedlings were incubated for $36 \mathrm{~h}$ in humid glass chambers at a temperature of $23 \pm 2^{\circ} \mathrm{C}$ and more than $85 \%$ relative humidity after which, the pots were shifted to muslin cloth chambers in the same green house. The disease reaction was recorded 12-14 days after inoculation, using the scoring method described by Stakman et al. [10].

\section{PCR amplification using molecular markers}

Twenty-four SSR markers specific to the 3D chromosome were selected from published data [11,12].The SSR markers (custom synthesized at Biobasic Inc, Canada) were used to screen the parents (PBW343-Lr24 and CSP44-Lr48), $\mathrm{F}_{2}$ population (comprising homozygous resistant, homozygous susceptible and heterozygous plants) and bulks (resistant and susceptible).

The PCR reactions with SSR markers were performed in a $20 \mu \mathrm{l}$ volume which consisted of $10 \mathrm{mM}$ Tris $\mathrm{HCl}(\mathrm{pH} \mathrm{8.3),} 50 \mathrm{mM} \mathrm{KCl}, 2$ $\mathrm{mM} \mathrm{MgCl}, 200 \mu \mathrm{M}$ of each dNTP (MBI Fermentas, Germany), $40 \mathrm{ng}$ of each of the forward and reverse primers, $0.75 \mathrm{U}$ Taq DNA polymerase (Banglore Genei Pvt. Ltd., India) and 50 ng template DNA. PCR amplifications for RAPD markers were done following the protocol developed by Williams et al. [13] in $20 \mu \mathrm{l}$ reaction volume containing $10 \mathrm{mM}$ Tris- $\mathrm{HCl}$ (pH 8.3), $50 \mathrm{mM} \mathrm{KCl}, 2 \mathrm{mM} \mathrm{MgCl}_{2}, 200 \mu \mathrm{M}$ of each dNTP (MBI Fermentas, Germany), $0.2 \mu \mathrm{M}$ of primer, $0.75 \mathrm{U}$ Taq DNA Polymerase (Bangalore Genei Pvt. Ltd., India) and 10-15 ng of genomic DNA. The amplification reactions were carried in a PTC-200 thermal cycler (MJ Research, Las Vegas, NV, USA) with the following thermal profile - initial denaturation of $94^{\circ} \mathrm{C}$ for $10 \mathrm{~min}$ followed by 44 cycles of $94^{\circ} \mathrm{C}$ for $1 \mathrm{~min}$ (denaturation), $60^{\circ} \mathrm{C}, 55^{\circ} \mathrm{C}$ and $36^{\circ} \mathrm{C}$ (for Xgwm114, Xbarc71 and RAPD markers respectively) for 1 min (annealing), $72^{\circ} \mathrm{C}$ (extension) and a final extension step of $72^{\circ} \mathrm{C}$ for $10 \mathrm{~min}$. This was followed by $4^{\circ} \mathrm{C}$ for $10 \mathrm{~min}$. The amplified products from SSR markers and RAPD markers were separated on a $3 \%$ Metaphor $^{\circledR}$ agarose gel and 2\% Agarose gel respectively, in $1 \mathrm{X}$ TAE buffer at $80 \mathrm{~V}$ for $3 \mathrm{hrs}$ to separate the fragments. The gels were later stained with $10 \mathrm{mg} / \mathrm{ml}$ ethidium bromide and viewed in a digital gel documentation system (Alpha Innotech, San Leandro, CA, USA).
Bulked segregant analyses were done to identify the markers' linkage to the dominant resistance gene. Ten randomly selected plants from the homozygous resistant and homozygous susceptible $\mathrm{F}_{2}$ plants were used to prepare bulks [14]. The bulks differentiated for the presence and absence of the leaf rust resistance gene Lr24 (Figure 1).

\section{Statistical analysis}

Segregation ratios were analyzed using a chi-square test. The individuals from the crosses that were scored as resistant and susceptible in the progeny populations were subjected to chi-square test for goodness of fit to test the deviation from the theoretically expected Mendelian segregation ratios. The linkage analysis was carried out using Mapmaker version 3.0 [15].

\section{Results}

\section{Phenotypic reaction}

The parent PBW343+Lr24 showed resistance to rust infection and recorded infection type (IT) of ; to 1 while the other parent CSP44 showed high level of susceptibility (IT of $33^{+}$) at seedling stage. At adult plant stage the parent PBW343+Lr24 remained resistant while the other seedling susceptible parent showed resistance by recording a ; reaction type. All the $\mathrm{F}_{1}$ plants remained resistant to the rust infection recording an infection type of ; to 1 .

46 seedlings of the $\mathrm{F}_{2}$ population showed susceptibility to the leaf rust infection while the remaining 136 plants remained resistant by expressing the seedling resistance conferred by the dominant resistance allele of the Lr24 locus and the population followed a monogenic segregation ratio. All the susceptible $\mathrm{F}_{2}$ derived $\mathrm{F}_{3}$ families remained susceptible whereas only 41 out of the 136 resistant $F_{2}$ derived $F_{3}$ families were homozygous for resistance. The remaining 95 families were heterozygous thus distributing the $F_{2}$ genotypes into 1R:2R:1S monogenic segregation ratio (Table 1 ). The phenotypic expression of adult plant resistance could not be examined due to the interference of the dominant seedling resistance gene Lr24 in the same genetic background.

(a)

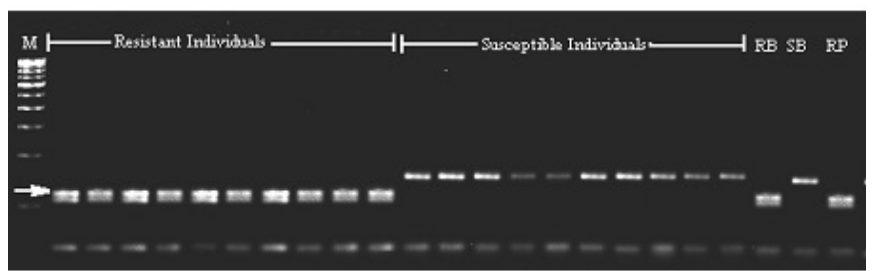

(b)

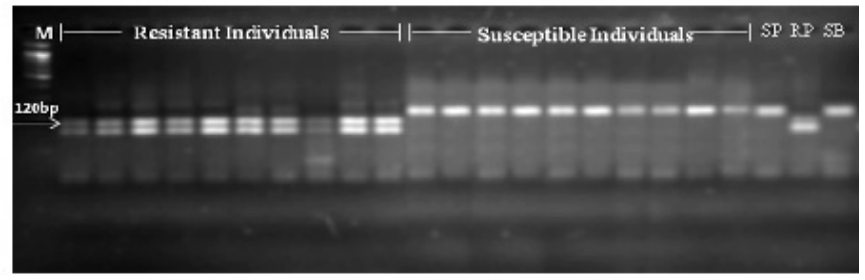

Figure 1: Screening of the SSR markers (a) Xgwm114 and (b) Xbarc71 on the bulked DNA constituent $F_{2}$ plants of the cross PBW343 + Lr24 $x$ CSP44Lr48 for genetic linkage analysis. 
Citation: Pallavi JK, Singh A, Usha Rao I, Prabhu KV (2015) Identification and Validation of a Microsatellite Marker for the Seedling Resistance Gene Lr24 in Bread Wheat. J Plant Pathol Microb 6: 276. doi:10.4172/2157-7471.1000276

\begin{tabular}{|c|c|c|c|c|c|c|c|}
\hline$F_{1}$ & \multicolumn{7}{|c|}{$F_{2}$ reaction ${ }^{*}$} \\
\hline $\mathbf{R}$ & \multicolumn{2}{|c|}{ Total tested } & $\mathbf{R}$ & $\mathbf{s}$ & \multicolumn{2}{|c|}{$\mathbf{X}_{3: 1}^{2}$} & $\mathbf{P}$ \\
\hline 16 & \multicolumn{2}{|l|}{182} & 136 & 46 & \multicolumn{2}{|c|}{0.0072} & 9323 \\
\hline \multicolumn{2}{|c|}{$\begin{array}{l}\text { No. of } F_{2} \text { families } \\
\text { for } F_{3} \text { testing }\end{array}$} & \multicolumn{4}{|c|}{$R$ in $F_{2}$} & \multicolumn{2}{|c|}{$S$ in $F_{2}$} \\
\hline $\mathbf{R}$ & $\mathbf{s}$ & NSeg & Seg & $X_{1: 2}^{2}$ & $\mathbf{P}$ & NSeg & Seg \\
\hline 136 & 46 & 41 & 95 & 0.6208 & 0.7331 & 46 & 0 \\
\hline
\end{tabular}

"R: Leaf Rust Resistant; S: leaf rust susceptible, \#NSeg: Non-Segregating Family for Leaf Rust; Seg: Segregating Family for Leaf Rust.

Table 1: Reaction of wheat plants in $F_{1}, F_{2}$ and $F_{3}$ generations of the cross Pbw343 $+L r 24 \times$ CSP $44+L r 48$ at seedling stage (DC 11) to infection by the leaf rus pathotype 77-5 under controlled conditions.

\section{Molecular marker study}

Out of twenty-four SSR markers specific to the 4AL chromosome, only two markers, Xgwm114(F:5' ACAAACAGAAAATCAAAACCCG 3' R: 5'ATCCATCGCCATTGGAGTG3') with annealing temperature of $60^{\circ} \mathrm{C}$ and Xbarc71 (F:5'GCGCTTGTTCCTCACCTGCTCATA3' R: 5'GCGTATATTCTCTCGTCTTCTTGTTGGTT3') with annealing temperature of $55^{\circ} \mathrm{C}$ were identified to be polymorphic between the parents. 10 randomly selected samples were taken from the resistant and susceptible plants to prepare bulks for bulk segregant analysis (Figure 1). The markers were found to be putatively linked to the Lr24 locus. The polymorphic SSR markers were analyzed on the 182 $\mathrm{F}_{2}$ plants for linkage analysis with the $\operatorname{Lr} 24$ locus. Both the markers were associated with the Lr24 locus and located at a distance of 2.4 cM from it (Table 2). The PBW343-Lr24 resistance allele linked SSR marker allele amplified a $120 \mathrm{bp}$ fragment and the CSP44 susceptibility allele linked marker allele amplified a $151 \mathrm{bp}$ fragment. The marker Xgwm114 differentiated the population into 45 homozygous resistant, 89 heterozygous resistant and 48 homozygous susceptible plants. The $120 \mathrm{bp}$ fragment was specific to the $L r 24$ resistance allele and did not amplify in other $L r$ genes carrying lines from other native and alien sources (Figure 2).

By employing the flanking RAPD markers $S 3_{450}$ (5'CATCCCCTG3') and $S 336_{775}$ (5'TCCCCATCAC3') linked respectively to the recessive resistance allele and dominant susceptible allele of the $\operatorname{Lr} 48$ locus; plants which were homozygous for recessive APR gene Lr48 were identified, as these two markers served as one co-dominant marker system capable of identifying both dominant and recessive alleles of heterozygous plants. $10 \mathrm{~F}_{2}$ plants were found to be the homozygous at both the dominant seedling resistance locus of $\operatorname{Lr} 24$ and the recessive adult plant resistance locus of $\operatorname{Lr} 48$ (Table 3).

\section{Discussion}

The Lr24 gene transferred from Agropyron elongatum is important to wheat since there are reports of its locus being linked to the stem rust resistance gene Sr24 [16]. The Agropyron chromosome segment is located on the satellite of chromosome $1 \mathrm{~B}$ and the translocation chromosome designated as T1BL-1BS-3Ae\#1L. T1BL-1BS-3Ae\#1L was inherited from Teewon wheat and carries resistance genes to stem rust $(S r 24)$ and leaf rust $(L r 24)$. Sr24 is highly effective against TTKS (Ug99), a recently emerged race with virulence to Sr31 that is considered to be a serious threat to wheat crop produce all over the world [17]. Though Xgwm114 has not been testified in populations segregating for stem rust resistance in this experiment, an assumption can be made that the identification of presence of $L r 24$ through this marker also suggests the existence of stem rust resistance. Such a marker will thus be economically important in wheat breeding programmes. Pathotypes virulent on $\mathrm{Lr} 24$ have been reported from North America , South America and South Africa [5,18-21]. This requires that Lr24 should be used only in combinations with other $L r$ genes. Worldwide, no virulence has been reported on the combination $\operatorname{Lr} 9$ and $\operatorname{Lr} 24$ [6].

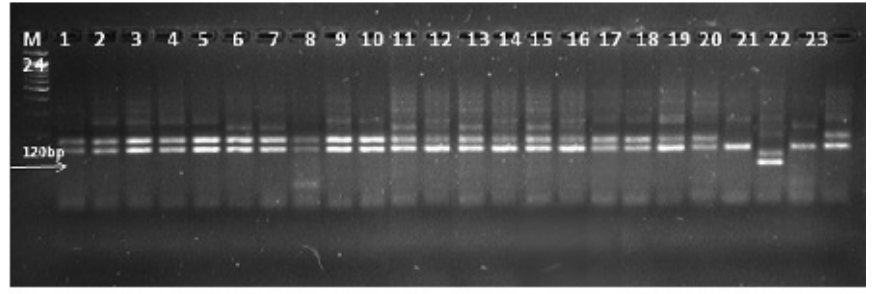

Legend (a): Lanes 1-20, NLs carrying different non-alien $L^{r}$ genes in the following order: $L r 1, L r 2 a, L r 3, L r 3 k a, L r 10, L r 11, L r 12, L r 13, L r 14 a, L r 14 b$, $L r 14 a b, L r 15, L r 16, L r 17, L r 18, L r 20, L r 22 b, L r 27+L r 31, L r 30, L r 33$; lane 21: CSP44Lr48, 22: Lr24, 23: Lr49, 24: Agra Local, M: 100-bpDNA ladder.

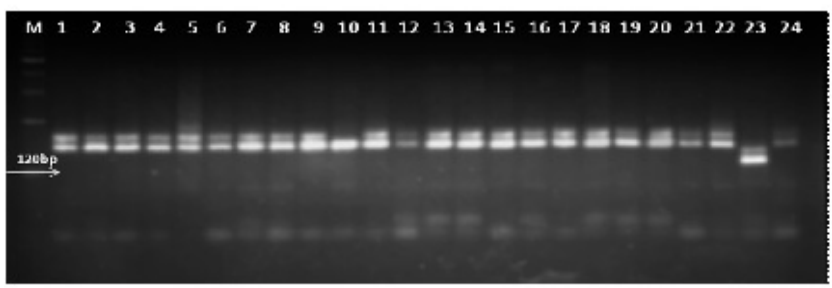

(b) Lanes 1-20, NILs carrying different alien $L r$ genes in the following order: $L r 9$, $L r 19, \operatorname{Lr} 21, \operatorname{Lr} 22 a, \operatorname{Lr} 23, \operatorname{Lr} 24, \operatorname{Lr} 25, \operatorname{Lr} 26, \operatorname{Lr} 27, \operatorname{Lr} 28, \operatorname{Lr} 29, \operatorname{Lr} 32, \operatorname{Lr} 35, \operatorname{Lr} 36$, $L r 37, L r 39, L r 40, L r 41, L r 42, L r 43$; lane 21: CSP44Lr48, 22: $L r 44,23: L r 24,24:$

\section{Agra Local, M: 100-bp DNA ladder}

Figure 2: Validation of the SSR marker Xgwm114 linked to leaf rust resistance gene $L r 24$ on a set of 21 (a) non-alien and (b) alien $L r$ genes in wheat.

\begin{tabular}{|c|c|c|c|c|c|c|c|c|c|c|c|c|c|c|c|}
\hline \multirow{2}{*}{ Loci } & \multicolumn{9}{|c|}{ Segregants } & \multicolumn{2}{|c|}{ Marker Fragment } & \multicolumn{2}{|c|}{$\begin{array}{l}L r 24 \text { gene \& marker } \\
\text { fragment }\end{array}$} & \multicolumn{2}{|c|}{ Linkage } \\
\hline & $++/ \mathbf{R}$ & $++/ R$ & $--/ \mathbf{R}$ & $++/ H$ & $++/ H$ & $--/ H$ & $++/ S$ & $++/ S$ & $--/ S$ & $\mathbf{X}_{1: 2: 1}^{2}$ & $\mathbf{P}$ & $\mathbf{X}^{2}$ 1:2:1:2:4:2:1:2:1 & $\mathbf{P}$ & $x^{2}$ & $\mathbf{P}$ \\
\hline Lr24-Xgwm11 & 41 & 0 & 0 & 4 & 89 & 2 & 0 & 0 & 46 & 0.1866 & 0.9109 & 326.87 & 0.00 & 329.68 & 0.00 \\
\hline Lr24-Xbarc71 & 41 & 0 & 0 & 2 & 93 & 0 & 2 & 0 & 44 & 0.0987 & 0.9518 & 326.69 & 0.00 & 336.70 & 0.00 \\
\hline
\end{tabular}

R: Homozygous Resistant; H: Heterozygous; S: Homozygous Susceptible

Marker Fragment

++ : Homozygous Resistant

$+-:$ Heterozygous

--: Homozygous Susceptible

Table 2: Test of linkage between the leaf rust resistance gene $L r 24$ and SSR markers (Xgwm114 and Xbarc71) in the $F_{2}$ population of the cross PBW343+Lr24 X CSP44Lr48 of wheat. 


\begin{tabular}{|c|c|c|c|c|c|c|c|}
\hline $\begin{array}{l}\mathrm{F}_{2} \text { plant } \\
\text { No. }\end{array}$ & $\begin{array}{l}\mathrm{S3}_{450} \\
\text { SCAR }\end{array}$ & $\begin{array}{l}\text { S336 } \\
\text { SCAR }\end{array}$ & $\begin{array}{c}\text { Genes } \\
\text { Carried } \\
(L r)\end{array}$ & $\begin{array}{c}F_{2} \\
\text { No. }\end{array}$ & $\begin{array}{c}\mathrm{S3}_{450} \\
\text { SCAR }\end{array}$ & $\begin{array}{l}\text { S336 }_{775} \\
\text { SCAR }\end{array}$ & $\begin{array}{c}\text { Genes } \\
\text { Carried } \\
(L r)\end{array}$ \\
\hline 1 & - & + & 24, & 31 & - & + & 24 \\
\hline 2 & - & + & 24 & $32^{*}$ & + & - & 24,48 \\
\hline 3 * & + & - & 24,48 & 33 & - & + & 24 \\
\hline 4 & - & + & 24 & 34 & - & + & 24 \\
\hline 5 & + & + & 24,48 & $35^{*}$ & + & - & 24,48 \\
\hline 6 & - & + & 24 & 36 & - & + & 24 \\
\hline $7^{*}$ & + & - & 24,48 & 37 & + & + & 24,48 \\
\hline 8 & - & + & 24 & 38 & - & + & 24 \\
\hline 9 & - & + & 24 & $39^{*}$ & + & - & 24,48 \\
\hline $10^{*}$ & + & - & 24,48 & 40 & - & + & 24 \\
\hline 11 & - & + & 24 & 41 & - & + & 24 \\
\hline 12 & - & + & 24 & & & & \\
\hline 13 & + & + & 24,48 & & & & \\
\hline 14 & - & + & 24 & & & & \\
\hline 15 & - & + & 24 & & & & \\
\hline 16 & + & + & 24,48 & & & & \\
\hline 17 & - & + & 24 & & & & \\
\hline $18^{*}$ & + & - & 24,48 & & & & \\
\hline 19 & - & + & 24 & & & & \\
\hline $20^{*}$ & + & - & 24,48 & & & & \\
\hline 21 & - & + & 24 & & & & \\
\hline $22^{*}$ & + & - & 24,48 & & & & \\
\hline 23 & - & + & 24 & & & & \\
\hline 24 & - & + & 24 & & & & \\
\hline 25 & + & + & 24,48 & & & & \\
\hline 26 & - & + & 24 & & & & \\
\hline 27 & - & + & 24 & & & & \\
\hline $28^{*}$ & + & - & 24,48 & & & & \\
\hline 29 & - & + & 24 & & & & \\
\hline 30 & - & + & 24 & & & & \\
\hline
\end{tabular}

Table 3: Marker assisted selection in segregating $F_{2}$ progeny of a cross $L r 24$ and $L r 48$ for $L r 48$ in PBW343 background. Only 41 plants with homozygous bands for Lr24 locus were screened with $\mathrm{S}_{450}$ and $\mathrm{S} 336_{775}$ RAPD markers. *homozygous for $L r 48$.

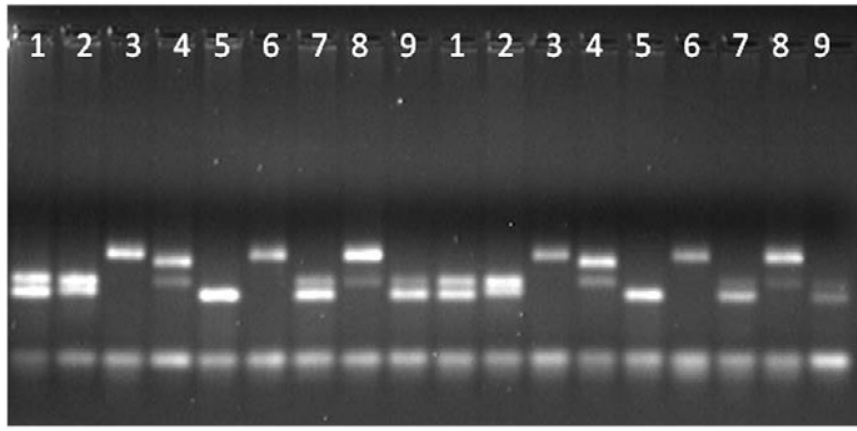

Figure 3: A gel depicting the extent of similarity in segregation between Xgwm114 and Xbarc71 in a segregating $F_{2}$ population.

Lr24 still continues to be highly effective in India and three cultivars Vidisha, Vaishali (DL784-3) and HW2004 carrying both Lr24/Sr24 have been released for commercial cultivation in India.

Several markers showing a dominant inheritance pattern have been reported to be linked to the $L r 24$ resistance locus. A SCAR marker developed by Cherukuri et al., [22] in the same laboratory is currently being successfully employed to track the transfer and establishment of this gene in different genetic background. A PCR-based DNA-STS marker, six RFLP markers completely linked to Lr24 - one inherited as a codominant marker (PSR1205), one in coupling phase (PSR1203), and four in repulsion phase (PSR388, PSR904, PSR931, PSR1067) were reported to be inherited with $L r 24$. A RAPD marker, OPJ-09 also was shown to be in complete linkage to the Lr24 resistance gene [23]. The markers have been used in wheat breeding experiments employing MAS [24]. There are other reports of plymorphic RAPD and SCAR markers for Lr24 by Dedryver et al., [25].

Simple sequence repeats DNA called microsatellites are ubiquitously distributed within the eukaryotic genome, and SSR is more polymorphic than other marker systems $[12,26]$. The genetic map constructed by Roder [26] uses microsatellite markers located on seven chromosome groups and Xgwm114 was located on chromosome arm $3 \mathrm{~B}$ and $3 \mathrm{D}$. Xgwm114 is reported to be associated with powdery mildew resistance in wheat [27]. Three microsatellite markers, Xgwm247, Xgwm181 and Xgwm114 located on chromosome 3BL, were shown to be associated with the stem solidness locus and with sawfly cutting in durum wheat [28]. McIntosh [29] reports the location of Lr24 on the long arm of 3D and the current experiment shows the linkage of Xgwm114 with the locus of Lr24.

Xbarc71 is reported to be sharing the same position on the long arm of 3D chromosome along with Xgwm114 in the chromosome map developed by Torada et al., [11]. This was reconfirmed by the pattern of segregation shown by both the markers in the $\mathrm{F}_{2}$ population (Figure 3 ). However, the same markers are placed considerably far apart in the chromosome map developed by Somers et al., [30,31]. In the present experiment, both the markers were able to differentiate the presence of Lr24 in segregating populations almost with equal precision and here we report that they can be used interchangeably to identify homozygous Lr24 locus.

Such codominant SSR markers will be extremely useful in large scale wheat breeding programmes where selection of homozygous resistant plants which potentially carry the resistance genes will be achieved at very early generations. A segregating $\mathrm{F}_{2}$ population will suffice to select plants in which the gene is fixed.

In this experiment, the pair of the RAPD markers also was valuable only because they could be employed as a codominant marker system. $\mathrm{S} 3_{450}$ was linked to the recessive adult plant resistance allele and $\mathrm{S} 336_{775}$ was linked to the dominant susceptibility linked allele of the Lr48 locus. Since both the alleles are easily differentiated, we could select those plants homozygous for the recessive resistance allele linked adult plant resistance at the $L r 48$ locus.

\section{References}

1. Kolmer JA (1996) Genetics of resistance to leaf rust. Anuual Review of Phytopathology 34: 435-455.

2. Mclntosh RA, Wellings CR, Park RF (1995) Wheat rusts: an atlas of resistance genes. Kluwer Academic Publishers, Dordrecht.

3. McIntosh RA, Yamazaki Y, Dubcovsky J, Rogers J, Morris C, et al. (2008) Catalog of gene symbols for wheat. $11^{\text {th }}$ International Wheat Genetics Symposium, Brisbane Qld Australia.

4. Tomar SMS, Menon MK (1998) Introgression of alien genes for leaf rust (Puccinia recondita) resistance in to bread wheat (Triticum aestivum L) cultivars. Indian J Agric Sci 68: 675-681.

5. Long DL, Roelfs AP, Leonard KJ (1994) Virulence and diversity of Puccinia recondite f. sp. tritici in United States in 1992. Plant Dis 78: 901-906.

6. Roelfs AP, Simmonds NW, Ajaram S (1988) Resistance to leaf rust and stem rust in wheat. Breeding Strategies for Resistance to Rust of Wheat 10-22.

7. Samsampour D, Zanjani BM, Singh A, Pallavi JK, Prabhu KV (2009) Marker 
Citation: Pallavi JK, Singh A, Usha Rao I, Prabhu KV (2015) Identification and Validation of a Microsatellite Marker for the Seedling Resistance Gene Lr24 in Bread Wheat. J Plant Pathol Microb 6: 276. doi:10.4172/2157-7471.1000276

assisted selection to pyramid seedling resistance gene Lr24 and adult plant resistance gene Lr48 for leaf rust resistance in wheat. Indian J Genet PI Breed 69: 1-9.

8. Prabhu KV, Somers DJ, Rakow G, Gugel RK (1998) Molecular markers linked to white rust resistance in mustard Brassica juncea. Theor. App Genet 97: 865870 .

9. Zadoks JC, Chang TT, Konzak CF (1974) A decimal code for the growth stages of cereals. Weed Res 14: 415-421.

10. Stakman EC, Stewart DM, Loegering WQ (1962) Identification of physiological races of Puccinia graminis var. tritici. Agricultural Research Service E617.

11. Torada A, Koike M, Mochida K, Ogihara Y (2006) SSR-based linkage map with new markers using an intraspecific population of common wheat. Genet 112 : 1042-105.

12. Roder MS, Korzun V, Wendehake K, Plaschke J, Tixier MH, et al. (1998) A microsatellite map of wheat. Genetics 149: 2007-2023.

13. Williams JGK, Kubelik AR, Livak KJ, Rafalski JA, Tingey SV (1990) DNA polymorphisms amplified by arbitrary primers are useful as genetic markers. Nucleic Acids Res 18: 6531-6535.

14. Michelmore RW, Paran I, Kesseli RV (1991) Identification of markers linked to disease resistance genes by bulked segregant analysis: A rapid method to detect markers in specific genomic regions by using segregating populations. Proc Natl Acad Sci 88: 9829-9832.

15. Lander ES, Green P, Abrahamson J, Barlow A, Daly MJ, et al. (1987) An interactive computer package for constructing primary genetic maps of experimental and natural populations. Genomics 1: 174-181.

16. Menon MK, Tomar SMS (2001) Transfer of Agropyron elongatum-derived rust resistance genes Sr24 and Lr24 into some Indian bread wheat cultivars. Wheat Info Serv 92: 20-24.

17. Singh RP, Hodson DP, Jin Y, Huerta- Espino J, Kinyua MG, et al. (2006) Current status, likely migration and strategies to mitigate the threat to wheat production from race Ug99 (TTKS) of stem rust pathogen. CAB Reviews: Perspectives in Agriculture, Veterinary Science, Nutrition and Natural Resources 1: 1-13.

18. Bowder LE (1973) Probable genotypes of some Triticum aestivum 'Agent' derivatives for reaction to Puccinia recondite f. sp. tritici. Crop Sci 13: 203-206.

19. Kolmer JA, Dyck PL, Roelfs AP (1991) An appraisal of stem and leaf rust resistance in North American hard red spring wheats and the probability of multiple mutations in populations of cereal rust fungi. Phytopathology 81: $237-$ 239 .
20. Singh RP, Rajaram S (1991) Resistance to Puccinia recondita f. sp. tritici in 50 Mexican bread wheat cultivars. Crop Sci 31: 1472-1479.

21. Pretorius ZA, Kemp GH (1990) Effect of growth stage and temperature on components of resistance to leaf rust in wheat genotypes with Lr26. Plant Disease 74: 631-635.

22. Cherukuri DP, Gupta SK, Charpe A, Koul S, Prabhu KV, et al. (2005) Molecular mapping of Aegilops speltoides derived leaf rust resistance gene Lr28 in wheat. Euphytica 143: 19-26.

23. Schachermayr G, Messmer M, Feuillet C, Winzeler H, Keller B (1995) Identification of molecular markers linked to the Agropyron elongatum-derived leaf rust resistance gene Lr24 in wheat. Genet 90: 982-990.

24. Slikova S, Gregova E, Bartos P, Hanzalova A, Hudcovicova M, et al. (2004) Development of wheat genotypes possessing a combination of leaf rust resistance genes Lr19 and Lr24. Plant Soil Environ 50: 434-438.

25. Dedryver F, Jubier MF, Thouvenin J, Goyeau H (1996) Molecular markers linked to the leaf rust resistance gene Lr24 in different wheat cultivars. Genome 39: $830-835$.

26. Roder MS, Plaschke J, Konig SU, Borner A, Sorrells ME, et al. (1995) Abundance, variability and chromosomal location of microsatellites in wheat. Molecular and General Genetics 246: 327-333.

27. Wang Z, Qi Z, Yongkang P, Chaojie X, Qixin S, et al. (2004) Identification of Random Amplified Polymorphic DNA and Simple Sequence Repeat markers Linked to Powdery Mildew Resistance in Common Wheat Cultivar Brock. Plant Prod Sci 7: 319-323.

28. Houshmand S, Ronald EK, Fran RC, John MC (2007) Microsatellite markers flanking a stem solidness gene on chromosome $3 \mathrm{BL}$ in durum wheat. Mol Breeding 20: 261-270.

29. McIntosh RA, Hart GE, Devos KM, Gale MD, Rogers WJ (1998) Catalogue of gene symbols for wheat. Proceedings of the Ninth International Wheat Genetics Symposium, University Extension Press, University of Saskatchewan, Saskatoon, Canada.

30. Somers DJ, Isaac P, Edwards K (2004) A high-density microsatellite consensus map for bread wheat (Triticum aestivum L). Genet 109: 1105-1114.

31. Tomar SMS, Menon MK (2001) Improvement of WH542 a Petkus rye derivative of bread wheat with additional genes for rust resistance. Annals Agri Res 3 : 303-308. 